\title{
Milk electrolytes and induction of parturition
}

\author{
D. L. Paccamonti \\ Equine Health Sciences Program, Department of Veterinary Clinical Sciences, School of Veterinary Medicine, Louisiana State University, USA
}

\begin{abstract}
Summary
Induction of parturition should not be viewed as a tool to make foaling more convenient but as a means by which proper veterinary care can be provided without delay when complications are anticipated. The best way to insure that veterinary assistance will be available when a mare foals is to induce parturition. However, because the equine gestation length is so variable, and inducing parturition before the foal is mature and capable of life outside the womb is an invitation for disaster, assessing fetal readiness for birth is paramount for achieving success. The best method to assess fetal readiness for birth is to measure calcium, sodium and potassium in the mammary secretions. A level of $10 \mathrm{mmol}$ (400 ppm) calcium, in combination with a concentration of potassium that is greater than that of sodium, is indicative of fetal maturity. However, with pregnancies complicated by problems such as placentitis or twins, milk electrolytes are unreliable for assessing fetal readiness for birth. Nevertheless, milk electrolytes may still be helpful in these cases to decide when close supervision is recommended. Regardless, care must be taken to understand the testing method used and thereby interpret the results. Usually, when parturition is induced it is done so because a high probability of complications exists. Therefore it is recommended to place an intravenous catheter prior to the induction procedure. Similarly, planning for possible complications such as dystocia, premature placental separation or neonatal problems before beginning the induction procedure will greatly speed their successful resolution if encountered. Although many methods for inducing parturition have been reported, a single low dose of oxytocin (10 IU, i.v. for a $550 \mathrm{~kg}$ mare) is preferred. Provided the criteria for readiness for birth have been met, a single low dose is sufficient to initiate the cascade of events leading to parturition and provides a more natural course of events than higher doses or repeated administration.
\end{abstract}

Keywords: $\quad$ horse, milk electrolytes, fetus, readiness for birth, induction of parturition

\section{Milchelektrolyte und Geburtseinleitung}

Die Einleitung einer Geburt ist die beste Methode, um eine ausreichende tierärztliche Versorgung ohne zeitliche Verzögerung in den Fällen zu gewährleisten, in denen Geburtsschwierigkeiten zu befürchten sind, und sollte auch nur in diesen Fällen in Betracht gezogen werden. Die Feststellung der Geburtsreife ist oberstes Gebot, um erfolgreich eine Geburt einzuleiten, da die Gestationslänge bei der Stute sehr variabel ist und die zu frühe Einleitung der Geburt lebensgefährlich für das Fohlen sein kann. Um die Geburtsreife des Fetus festzustellen, ist die Messung von Kalzium, Natrium und Kalium im Eutersekret die beste Methode. Ein Gehalt von 10 mmol (400 ppm) Kalzium in Kombination mit einer höheren Konzentration von Kalium als von Natrium spricht für die fetale Reife. Allerdings sind bei Komplikationen der Trächtigkeit, wie Plazentitis oder Zwillingsträchtigkeiten, die Milchelektrolyte zur Feststellung der Geburtsreife unzuverlässig. Trotzdem können die Milchelektrolyte auch in diesen Fällen bei der Entscheidung hilfreich sein, um zu entscheiden, ab wann eine genaue Geburtsüberwachung empfehlenswert ist. In jedem Fall muss Sorgfalt angewendet werden, um die verwendeten Testmethoden zu verstehen, und somit die Ergebnisse zu interpretieren. Normalerweise wird eine Geburt eingeleitet, wenn Komplikationen wahrscheinlich sind. Daher wird empfohlen, bereits vor der Geburtseinleitung einen intravenösen Katheter anzulegen. Auch sollten bereits vorher für die möglichen Komplikationen wie Schwergeburt, verfrühte Plazentaablösung oder neonatale Probleme Vorbereitungen getroffen werden, um für eine diesbezügliche schnelle und erfolgreiche Lösung zu sorgen, sollten diese eintreten. Obwohl viele Methoden zur Geburtseinleitung beschrieben wurden, wird eine einzelne niedrige Dosis Oxitocin (10 IU, i.v. für eine $550 \mathrm{~kg}$ schwere Stute) bevorzugt.

Vorausgesetzt, dass die Kriterien für die Geburtsreife eingetreten sind, ist eine einzelne niedrige Dosis ausreichend, um die Kaskade der Ereignisse, die zur Geburt führen, einzuleiten und sie gewährleistet einen natürlicheren Geburtsverlauf als höhere Dosen oder wiederholte Gaben.

Schlüsselwörter: Pferd, Milchelektrolyte, Fetus, Geburtsreife, Geburtseinleitung

Pregnant mares with potential problems require close supervision for a successful foaling outcome. Mares with a ruptured prepubic tendon or a pelvic fracture may need assistance during delivery. Mares carrying suspected twins, or those with a history of previous dystocia, placentitis, premature placental separation or neonatal isoerythrolysis are further examples of situations where it is prudent to have veterinary assistance available at the time of foaling. However, gestation length is notoriously unpredictable in mares. Therefore, it is often difficult to ensure prompt veterinary care at the time of delivery. Induction of parturition provides a means by which veterinary assistance can be assured to be available at foaling. In the past, induction of parturition was not looked upon favorably in equine studfarm medicine because it often resulted in the birth of a premature foal that had a poor chance of survival. Clearly, what was missing was a means to reliably determine fetal maturity and the foal's ability to survive outside the womb.

Peaker et al., (1979) measured components of mammary secretions pre-partum and found that calcium rose to $10 \mathrm{mmol} /$ $\mathrm{L}$ or greater, one to six days before foaling. This was followed by additional reports confirming a rapid pre-partum rise in calcium in mammary secretions (Leadon et al., 1984; Ousey et al., 1984). Furthermore, it was found that the relative concentrations of sodium and potassium invert, with potassium concentrations becoming greater than sodium in the last few days of gestation (Ousey et al., 1984). Based on these characteristic changes, mammary secretions were deemed to be a very good way to assess fetal maturity or "readiness for birth" 
(Leadon et al., 1984; Ousey et al., 1984). Foals born from mares induced to foal when calcium was less than $10 \mathrm{mmol} / \mathrm{L}$ had a poorer chance for survival compared with foals induced when calcium was greater than $10 \mathrm{mmol} / \mathrm{L}$ (Leadon et al., 1984; Ousey et al., 1984).

Water hardness kits are useful for determining the concentration of calcium in mammary secretions (Camillo et al., 1992; Cash et al., 1985; Ousey et al., 1989). However, the use of water hardness test kits is not without potential problems. Many kits test for divalent cations, which includes magnesium as well as calcium. Magnesium begins to increase earlier than calcium, and the rise is more gradual. Because of this slower, earlier rise in magnesium, water hardness tests which do not differentiate between magnesium and calcium complicate interpretation of results. Furthermore, the peak concentration of magnesium is reached earlier than is calcium and magnesium often declines at parturition (Ousey et al., 1989; Rook et al., 1997). For these reasons, if using a test to decide when to induce parturition, it is critical that a test that measures only calcium be used. If the intent is merely to determine the likelihood of the mare foaling on a particular night, the type of test is not as critical, however those that test for only calcium will have a better predictive value.

Another potential confounding factor in the interpretation of milk calcium test results is that in the presence of placentitis or with twin pregnancy, there is often a premature rise in calcium. Elevated milk calcium before $310 \mathrm{~d}$ has been suggested to be an indication of an abnormal pregnancy (Rossdale et al., 1991). Obtaining additional information by determining the concentration of sodium and potassium, in addition to calcium, is recommended if possible. If calcium is greater than $400 \mathrm{ppm}$, yet sodium remains greater than potassium, parturition should not be induced because a high probability of placentitis or undiagnosed twins exists.

Given that $10 \mathrm{~mol} / \mathrm{L}(400 \mathrm{ppm})$ calcium in mammary secretions has been well established as being a good indicator of fetal readiness for birth (Ousey et al., 1984, 1989; Peaker et al., 1979; Rook et al., 1997) test results should be interpreted keeping this standard in mind. Some manuscripts have referred to 200 or $250 \mathrm{ppm}$ calcium carbonate as benchmarks for readiness for birth (Ley et al., 1989, 1993). This is an error on two counts. First, calcium in milk is not in the form of calcium carbonate. Results from tests that measure calcium carbonate in a solution should be converted to calcium for interpretation. To convert ppm calcium carbonate to ppm calcium, results should be divided by 2.5 , because the molecular weight of calcium carbonate is 100 and the molecular weight of calcium is $40(100 \div 2.5=40)$. Furthermore, $\mathrm{ppm}$ is derived by multiplying mmol X molecular weight. Therefore, 200 and 250 ppm calcium carbonate are equivalent to only 80 and 100 ppm calcium, respectively, or 2 and $2.5 \mathrm{mmol}$ calcium carbonate or calcium ( $\mathrm{mmol}$ are not dependent on molecular weight). Moreover, mare mammary secretions usually need to be diluted before a water hardness test can be used to measure calcium. Therefore, if $1 \mathrm{ml}$ of milk is diluted with $4 \mathrm{ml}$ of distilled water, the test result should be multiplied by 5. As an example, a common test in the United States (Titrets, Chemetrics, Calverton, $\mathrm{VA})$ is designed to measure calcium carbonate in water. If a dilution is made using $1 \mathrm{ml}$ milk and $4 \mathrm{ml}$ water, the test result should then be doubled to give ppm calcium.

(test result X 5) to correct for dilution effect

(test result $\div 2.5$ ) to convert calcium carbonate to calcium (test result X $5 \div 2.5=$ test result $X 2$ ).

The reports using 200 or $250 \mathrm{ppm}$ as an indication of readiness for birth (Ley et al., 1989, 1993) are seemingly at odds with the original reports examining milk electrolytes (Ousey et al., 1984, 1989; Peaker et al., 1979) which established $10 \mathrm{mmol}(400$ ppm) as an indication of readiness for birth. However, in the manuscript using 200 ppm calcium carbonate (uncorrected results), as a predictor of foaling (Ley et al., 1993), if the value is corrected for dilution and converted to calcium, the benchmark used is actually $560 \mathrm{ppm}$ calcium, equivalent to $14 \mathrm{mmol} / \mathrm{L}$, which is in agreement with the earlier reports (Leadon et al., 1984; Ousey et al., 1984, 1989).

Milk calcium is also used for estimating the likelihood of a mare foaling on a given night. In general, tests are more reliable for judging when a mare is unlikely to foal than for predicting when she is likely to foal (Ousey et al., 1989). Of course, one reason for this is a mare's apparent ability to control when she goes into labor. It is a common observation that mares can seemingly withhold the onset of labor until surrounding conditions are suitable (Newcombe \& Nout, 1998). It is not unheard for a mare with a milk calcium greater than $10 \mathrm{mmol} / \mathrm{L}$, that is moved to a new environment where there is a lot of activity, to not foal for days, even after milk calcium reaches $25 \mathrm{mmol}$.

Another factor to consider in the interpretation of milk calcium tests is the rate of change. In general, the more rapid the rise, the more imminent is foaling. For example, a mare that has had calcium levels of 200, 195, 225, 225, 250, 250 and 500 ppm over the last week is more likely to foal that night than a mare that has had calcium levels of 200, 225, 250, 300, 325, 375 and $450 \mathrm{ppm}$. Calcium levels can also change rapidly during the day. A mare may have a milk calcium of only 300 ppm in the morning and over 700 by evening. Therefore, obtaining a sample for testing should either be done twice daily or late in the day.

Induction of parturition in mares is usually practiced when a high probability of complications or problems exists. Therefore extra precautions before beginning the procedure are warranted. Placing an intravenous catheter for the administration of oxytocin may seem unnecessary in most cases but should complications arise that require intravenous administration of anesthetic agents or other drugs, it will prove fortunate. Similarly, preparations should be made in advance for any complications that may possibly arise. Obstetrical equipment and lubricant, supplies for neonatal care, etc. should be readied before beginning the induction procedure.

Many dosages and routes of administration of oxytocin have been suggested for induction of parturition in mares (Camillo et al., 2000; Macpherson et al., 1997; Paccamonti, 1991). While many are effective, the guiding principle should be to mimic the natural process. Therefore, a single low dose of oxytocin is preferred (Camillo et al., 2000; Paccamonti, 1991). Higher doses cause a more violent and rapid delivery. Low doses, provided that the fetus has been determined to be "ready for birth" are sufficient to stimulate the cascade of events leading to parturition. 
A single dose of $10 \mathrm{U}$ oxytocin, i.v., will result in the initiation of Stage II of delivery within 30 minutes of administration. Repeat administration is rarely necessary. Provided the criteria for readiness for birth have been met, complications are not expected. The incidence of retained placenta after induction of parturition is not increased and foal viability is normal.

\section{Literature}

Camillo, F., Cela, M., Romagnoli, S., Grassi, F., Marmorini, P., Duchamp, G. and Palmer, E. (1992): Day-time management of the foaling mare: Use of a rapid mammary $\mathrm{Ca}++$ determination followed by a low dose of oxytocin. Proc. 12th Int. Cong. Anim. Reprod., 2, 883-885.

Camillo, F., Marmorini, P., Romagnoli, S., Cela, M., Duchamp, G. and Palmer, E. (2000): Clinical studies on daily low dose oxytocin in mares at term. Equine Vet. J., 32, 307-310.

Cash, R. S. G., Ousey, J. C. and Rossdale, P. D. (1985): Rapid strip test method to assist management of foaling mares. Equine Vet. J., 17, 61-62.

Leadon, D. P., Jeffcott, L. B. and Rossdale, P. D. (1984): Mammary secretions in normal spontaneous and induced premature parturition in the mare. Equine Vet. J., 16, 256-259.

Ley, W. B., Hoffman, J. L., Meacham, T. N., Sullivan, T. L., Kiracofe, R. L. and Wilson, M. L. (1989): Daytime management of the mare. 1: Pre-foaling mammary secretions testing. J. Equine Vet. Sci., 9, 8894.

Ley, W. B., Bowen, J. M., Purswell, B. J., Irby, M. and Greive-Crandell, K. (1993): The sensitivity, specificity and predictive value of measuring calcium-carbonate in mares prepartum mammary secretions. Theriogenology, 40, 189-198.

Macpherson, M. L., Chaffin, M. K., Carroll, G. L., Jorgensen, J., Arrott, C., Varner, D. D. and Blanchard, T. L. (1997): 3 Methods of oxytocininduced parturition and their effects on foals. J. Am. Vet. Med. Assoc., 210, 799-803.

Newcombe, J. R. and Nout, Y. S. (1998): Apparent effect of management on the hour of parturition in mares. Vet. Rec., 142, 221-222.
Ousey, J. C., Dudan, F. and Rossdale, P. D. (1984): Preliminary studies of mammary secretions in the mare to assess foetal readiness for birth. Equine Vet. J., 16, 259-263.

Ousey, J. C., Delclaux, M. and Rossdale, P. D. (1989): Evaluation of three strip tests for measuring electrolytes in mares' pre-partum mammary secretions and for predicting parturition. Equine Vet. J., $21,196-200$.

Paccamonti, D. L. (1991): Elective termination of pregnancy in mares. J. Am. Vet. Med. Assoc., 198, 683-688.

Peaker, M., Rossdale, P. D., Forsyth, I. A. and Falk, M. (1979): Changes in mammary development and the composition of secretion during late pregnancy in the mare. J. Reprod. Fertil., Suppl. 27, 555-561.

Rook, J. S., Braselton, W. E., Nachreiner, R. F., Lloyd, J. W., Shea, M. E., Shelle, J. E. and Hitzler, P. R. (1997): Multielement assay of mammary secretions and sera from periparturient mares by inductively-coupled argon plasma emission-spectroscopy. Am. J. Vet. Res., 58, 376378.

Rossdale, P. D., Ousey, J. C., Cottrill, C. M., Chavatte, P., Allen, W. R. and McGladdery, A. J. (1991): Effects of placental pathology on maternal plasma progestagen and mammary secretion calcium concentrations and on neonatal adrenocortical function in the horse. J. Reprod. Fertil., Suppl. 44, 579-590.

Dale Paccamonti, D.V.M., MS, Diplomate

American College of Theriogenologists

Professor, Theriogenology

Department of Veterinary Clinical Sciences

School of Veterinary Medicine

Lovisiana State University

Baton Rouge, Lovisiana, USA 70803

Tel: 225-578-9500

Fax: 225-578-9559

e-mail:pacc@lsu.edu 